Vol. 2, No. 2, December 2021

DOI: https:// doi.org/10.18196/ijiep.v2i2.12572

\title{
The Relationship Between Self-Regulation, Self-Efficacy, and Psychological Well-Being Among the Salahaddin University Undergraduate Students in Kurdistan.
}

\author{
Reben Ramadhan Salleh, Nik Ahmad Hisham Ismail* , Faizah Idrus \\ International Islamic University Malaysia, Malaysia
}

*Corresponding email: nikahmad@iium.edu.my

ARTICLE INFO

Article History

Received : 18/08/2021

Revised : 02/12/2021

$17 / 12 / 2021$

Accepted: 23/12/2021

Keywords

Growth and Development, Psychological Well-Being Self-Regulation, SelfEfficacy, Undergraduate Students

\section{ABSTRACT}

Self-regulation, self-efficacy, and psychological well-being are essential requirements in the academic environment. Psychological well-being is indispensable for students' emotional balance and healthy growth and development. The recent study investigated the relationship between self-regulation, self-efficacy, and psychological well-being among Kurdish students at Salahaddin University. The objectives of the research are as follows: (1) to examine the prevalence level of selfregulation, self-efficacy, and psychological well-being among the Salahaddin University undergraduate students; (2) to examine the relationship of self-regulation and self-efficacy with psychological well-being among the Salahaddin University undergraduate students; and (3) to examine the effect of self-regulation and self-efficacy on psychological well-being among the Salahaddin University undergraduate students. The study employed quota sampling, and there were 407 respondents selected for it. Analysis techniques were presented in descriptive, Pearson Correlation, and Multiple Regression Analysis (MRA). The research shows a low level of self-regulation and self-efficacy among the Salahaddin University undergraduate students. However, psychological well-being is high. The study further demonstrates a positive and statistically significant relationship between self-regulation, self-efficacy, and psychological well-being among the Salahaddin University undergraduate students. Finally, the study showed that only self-regulation significantly affected psychological well-being among the Salahaddin University undergraduate students.

This is an open access article under the CC BY-SA license.

\section{Citation:}

Salleh, R. R., Ismail, N. A. H. \& Idrus, F. (2021). The relationship between self-regulation, selfefficacy, and psychological well-being among the Salahaddin University undergraduate students in Kurdistan. International Journal of Islamic Educational Psychology, 2(2), 105-126. DOI: https:// doi.org/10.18196/ijiep.v2i2.12572 
Salleh, Ismail \& Idrus | The Relationship Between Self-Regulation, Self-Efficacy, and Psychological WellBeing Among the Salahaddin University Undergraduate Students in Kurdistan.

\section{INTRODUCTION}

Educational institutions play an important role in students' lives. As part of the educational sector, educational institutions help students grow and develop appropriately according to their abilities and capabilities. Thus, university students acquire the proper opportunity to comprehend their abilities and capabilities, manage themselves, and adopt strategic ways to pursue their objectives and targets in life.

Self-regulation allows students to get along with others well and enhances goal setting. Students with low self-regulation may face mental and behavioral issues and academic-based problems. On the other hand, having self-regulation increases academic success, social competence, and positive development (Zimmerman, 2000). Self-regulation is defined as a strategy of beliefs, feelings, and behaviors that inspire individual objectives (Ghonsooly \& Ghanizadeh, 2013). High self-regulation evaluates self-control and accelerates academic achievement across the learning process (Montroy, 2014).

Additionally, self-regulation has a connection with individual performance, which includes setting priorities, plan of activities, and monitoring progress (Beeftink et al., 2012). Self-regulation refers to the learning process to improve learners' activities to involve interpersonal, motivation, cognitive, and metacognitive terms. The improvement of self-regulation allows students to rationally consider multiple experiences across various realms: academic achievement, personality, social skills, and psychological well-being (McMillan, 2010; Pintrich, 2004). Los (2014) suggested that students' academic success is due to appropriating self-regulation within cognitive strategies, metacognitive strategies, and resource management.

According to (Bandura, 1996), self-efficacy refers to the understanding of the individual capacity to produce strategies to control current conditions. He explained that capacity affects life goals directly connected to emotions, feelings, and attitudes (Howatt, 2011). Bandura discovered the missing part of the developmental theory to maintain the confidence or willingness to accomplish functions and acquire capabilities (Pajares \& Schunk, 2002). Also, the idea of personal self-efficacy was the main point for this theory (Behjoo, 2013). According to Bandura, self-efficacy is distinguished as peoples' beliefs about their ability to produce an appropriate level of performance in improving human production and individual well-being (Pajares \& Schunk, 2002).

Furthermore, belief drives people to approach their objectives (Ghonsooly \& Ghanizadeh, 2013). Moreover, the presumption of people's skills will make them available to vanquish complicated tasks instead of threatening or trying to avoid difficulties (Bandura, 1994). Also, Pajares posits that people with a firm selfefficacy take on more difficult tasks (Motlagh et al., 2011).

Bandura (1994) laid down four causes of self-efficacy. They are vicarious experiences, enactive mastery, verbal persuasions, and physiological beings 
Salleh, Ismail \& Idrus | The Relationship Between Self-Regulation, Self-Efficacy, and Psychological WellBeing Among the Salahaddin University Undergraduate Students in Kurdistan.

(Feist et al., 2013). Students with a high level of self-efficacy are claimed to be a better predictor of academic outcomes than previous achievements or intrinsic ability without understanding abilities consciously (Los, 2014). Having high levels of self-efficacy motivates confidence in representatives and holding regular common performance to begin the consideration of the ability to regulate an individual's behavior. From Bandura's point of view, self-efficacy is recognized separately from other similar constructs, such as self-esteem and selfconcept. Self-esteem refers to the assessment of one's self, and self-concept considers individuality, for instance, different identity from others. Thus, selfesteem and self-concept refer to internal feelings for someone who notices the self. Still, self-efficacy draws the beliefs or expectations of individuals in the capabilities to deliver specific tasks (Los, 2014). Therefore, knowing capabilities is crucially important, especially for university students, to obtain a satisfactory outcome to enhance social contraction as basic psychological well-being. In addition, high self-efficacy obtains high levels of communication proficiency (Wildauer, 2017). The expectations of efficacy attempt individuals to determine appropriate actions to strengthen their activities (Bandura, 1994b). It greatly influences academic success and students' responsibilities practically instead of imagining. Besides, students will predict and design to fulfill activities based on unique skills. Self-efficacy influences advanced functions for estimating students' activities to increase academic motivation (Zimmerman, 2000). Furthermore, selfefficacy decreases stress and promotes academic achievement (Siddiqui, 2015).

Psychological well-being has become a controversial term in the half of the last century to concentrate on human development, life challenges, and the contribution of individuals' complete growth and improvement. In addition, psychologists were interested in discourses on individualization (Jung, 1931; Ryff \& Singer, 1996; and Zappala, 2007), fully functioning (Rogers, 1961); and selfactualization (Maslow, 1968) to describe the extension of growth and development of an individual. According to Diener (2000), the cognitive and emotional assessments of a person's existence have been defined as psychological well-being, including warm responses to events with cognitive happiness and fulfillment decisions (Zappala, 2007). Psychological well-being usually requires ideas which are happiness, self-actualization, vitality, self-acceptance, existence with meaning, optimum functioning, and satisfaction with life. Psychological well-being leads to the meaning of life, personal development, mastery, autonomy, satisfaction with life, positive effects, consistency, and hopefulness (Trudel-Fitzgerald et al., 2019). Psychological well-being can change their current circumstances. The absence of psychological well-being causes people to depend on external conditions, blaming the self for any reason and estimating the condition as permanent (Zappala, 2007).

Bandura's Social Cognitive Theory (SCT) includes self-regulation and selfefficacy components. In the case of self-regulation, individuals regulate behavior by internal reinforcement or punishment. At the same time, self-efficacy refers to an individual's belief in attaining desirable goals due to their actions (Zhou \& 
Salleh, Ismail \& Idrus | The Relationship Between Self-Regulation, Self-Efficacy, and Psychological WellBeing Among the Salahaddin University Undergraduate Students in Kurdistan.

Brown, 2015). SCT indicates environmental influences on human functions as evidence that individuals are not singularly affected through internal or external sources while these components (i.e., person, environment, and behavior) are inter-played reciprocally. A sense of self and recognizing individuals' expectations are profoundly affected by person, environment, and behavior and play important roles in students' learning, achievement, and psychological wellbeing, especially during college years (Saroughi, 2021). The theory focuses on producing a sense of self and adjusting to the everyday experiences of life (Roberts, 2007). According to Bandura, there is a causal relationship between perceived self-efficacy and behavioral adjustment (Zhou \& Brown, 2015). From the perspective of social cognitive theory, self-regulation has an important role in regulating individuals' external situations and attitudes to regulate their thoughts, behavior, and actions (Saroughi, 2021). Self-efficacy can improve the student population's learning abilities, life fulfillment, and well-being as a whole. These self-efficacy and self-regulatory strategies can subsequently allow them to control their emotions, thoughts, and behaviors (Saroughi, 2021).

University students face challenges in choosing specializations, living in the dormitory, thinking about future life, and suffering from academic stress as they consider the next stages of their academic and non-academic plans (Dierkes, 2020). These problems extend to securing a job after graduation and attaining good grades. These are some concerning dilemmas as they may affect selfregulation and self-efficacy on psychological well-being among undergraduate university students. The current pandemic adds to this puzzle as physical classes are reduced, and the need to keep social distance due to the threat of the disease can impact students' psychological well-being (Abdulkarim \& Suud, 2020). Considering the psychological dimension during the Coronavirus outbreak, world governments are more concerned about vaccinations and healthcare than the psychological aspect. In addition, students may face difficulties in their studies if they fail to regulate themselves in making decisions and to obtain psychological well-being. Because they have no adequate idea about their abilities, they can easily face any psychological symptoms. Klassen and Usher (2010) introduced self-efficacy as an indispensable factor throughout educational settings for students' prognosticating to advance their positions and academic activities. Students' level of self-efficacy in the learning process is a positive experience for their academic challenge that will strengthen their confidence to achieve and accomplish in a particular subject and decide for an academic specialization (Los, 2014). The literature has shown the absence of a study that examines self-regulation, self-efficacy, and psychological well-being among Kurdish students. Even less study considered university students' self-efficacy and self-regulation. As self-efficacy can also be implemented to psychological well-being (Taştan, 2014), exploring a unique strategy to enhance students' selfregulation will significantly reduce stress and improve their psychological wellbeing (Dierkes, 2020). There is an inadequate study between self-regulation and self-efficacy and university students' psychological well-being domains such as 
Salleh, Ismail \& Idrus | The Relationship Between Self-Regulation, Self-Efficacy, and Psychological WellBeing Among the Salahaddin University Undergraduate Students in Kurdistan.

personal growth, purpose in life, positive relations with others, autonomy, selfacceptance, and environmental mastery. Ghonsooly and Ghanizadeh (2013) showed a dynamic and reciprocal relationship between self-regulation, selfefficacy, and psychological well-being domains.

The recent study aims to study: (1) the prevalence level of self-regulation, selfefficacy, and psychological well-being (2) the relationship between selfregulation and self-efficacy with psychological well-being (3) determine the effect of self-regulation and self-efficacy on psychological well-being among the Salahaddin University undergraduate students.

\section{Self-Regulation, Self-Efficacy and Psychological Well-being}

Well-being includes two central perspectives, which are hedonia and eudaimonia. Hedonia refers to approaching environmental and emotional comfort, having a pleasant effect, and absence of unpleasant effects. Hedonia means overall satisfaction (subjective well-being). On the other hand, the eudaimonia view implies attempting to self-develop consistently with one's values and full psychological actualization (objective well-being) (Giuntoli et al., 2021; Vázquez et al., 2009). The objective understanding of psychological wellbeing was investigated firmly through Ryff's framework (Ryff \& Singer, 1996). Carol Ryff established the six components of psychological well-being (Howatt, 2011). According to Ryff, psychological well-being consists of six dimensions, and her perspective of psychological well-being is multidimensional as it encompasses self-acceptance, positive relations with others, autonomy, environmental mastery, purpose in life, and personal growth (Ryff, 2013). Ryff developed a questionnaire to measure psychological well-being based on these six dimensions. This scale has been used extensively among researchers to measure psychological well-being, and these dimensions are correlated dramatically with existing indicators that focus on feeling healthy, happy, optimistic, or happy with life (Ryff, 2013). Ryff relied on self-actualization theories of Abraham Maslow, Roger's full function, Allport's maturation, Erick Erikson's development stages, Carel Jung's formation, Buhler's human basic tendencies, Newgarten's executive personality process, and Jahoda's mental health (Ramli, 2017).

Self-acceptance has become a fundamental ingredient of mental health and selfactualization. It refers to a positive psychological characteristic based on acceptance, even having a positive feeling about past life, keeping an optimistic outlook on oneself and one's history (Durand-Bush et al., 2015). Self-acceptance significantly affects personal standards to enhance mental well-being, selfactualization, optimum functioning, and maturity. Positive psychological functioning is established through self-acceptance as a necessary level (Mongiovi, 2018). Self-acceptance is an individual assessment of various aspects of life. Ryff and Singer (2006) believe optimistic perspective will offer selfacceptance to positive aspects and even feeling healthy about previous life experiences, Maslow's self-actualization, Roger's optimum functioning, Allport's 
Salleh, Ismail \& Idrus | The Relationship Between Self-Regulation, Self-Efficacy, and Psychological WellBeing Among the Salahaddin University Undergraduate Students in Kurdistan.

maturity, and Erikson's acceptance of life are the philosophies that support this scale of psychological well-being (Howatt, 2011). Self-acceptance encourages selfevaluation that will influence awareness and acceptance about strengths and weaknesses. In addition, self-acceptance relates to the individual's sense of self about current and previous times that can alter actions, motivations, and feelings.

A positive relationship with others is a significant source of connection with others (Ryff, 2013). Getting quality interpersonal interactions with others is important to achieve social welfare. Individuals need pleasantness and connections to grow socially and develop strong empathy, love, and intimacy. Warmth, friendship, taking care of each other, and reliable attention are factors that allow positive relations with others. This dimension emerges based on the hypotheses of Aristotle's ethics, Russell's work on affection, Allport's maturity, and Erickson's development stage theory (Howatt, 2011). The number of friends, meeting duration, social event attendance, and social group membership relationship with satisfaction (Roberts, 2007). Love, strong friendship, and further communication with others can be influenced by a strong expression of empathy (Ryff \& Singer, 1996).

Autonomy refers to seeking people's values (Ryff, 2013). Autonomy as a dimension of psychological well-being is emphasized in the self-determination theory to determine self-confidence and self-regulation. Further, Black and Ryan believe that students' level of independent self-regulation can reduce anxiety levels across the semester (Mongiovi, 2018). According to (Ryff \& Singer, 1996), autonomy refers to individuality, the capability to resist social and peer influence, think and behave how people want, and make decisions to fulfill personal desires and values. The autonomous functioning of Maslow emphasizes this ability, Jung's individuation, the self-determination of Sartre, and the acquisition of a sense of liberation by Erikson (Howatt, 2011). Psychological wellness and efficient behavioral consequence are influenced by autonomy orientation (Deci \& Ryan, 2008).

Environmental mastery refers to the individual's level of competence to manage environmental activities for producing a positive psychological purpose. It empowers people to practice or establish suitable conditions to manage and control serious dynamic situations (Mongiovi, 2018). This component can improve psychological well-being and mental health. Both Jahoda's theory of an individual's ability and Allport's maturity emphasize environmental mastery (Howatt, 2011).

The dimension of purpose in life refers to an individual feeling how they sense or approach purpose and direction in life (Ryff, 2013). Psychological well-being will be high because of the direction in life (Mongiovi, 2018). Furthermore, purpose drives an individual to follow targets and find internal energy as an encouraging system in all aspects of life. The people who have a purpose in life can make a plan clearly and work properly to obtain a satisfactory result. 
Salleh, Ismail \& Idrus | The Relationship Between Self-Regulation, Self-Efficacy, and Psychological WellBeing Among the Salahaddin University Undergraduate Students in Kurdistan.

Working on individual goals provides a sense of control over life and enhances psychological well-being (Roberts, 2007).

Personal growth is defined as a sense of improvement consistent new life experiences necessary to determine the individual's potential. In selfactualization, personal development leads to a complete individual functioning in the family, job connection, and social experiences (Ryff, 2013). Personal growth means realizing one's potential, self-realization to control all life aspects (Ryff \& Singer, 1996). Several studies have shown that focusing on extrinsic and intrinsic targets correlates with productivity, better health, and psychological well-being (Deci \& Ryan, 2008).

\section{METHODS}

A survey was utilized in this study. A questionnaire was used to collect the data in the field research. Coghlan and Brydon-Miller (2014) asserted that quantitative research design such as a survey could provide a space for people to share personal information in an anonymous way that they would otherwise be unwilling to share with an interviewer. In this study, the non-probability quota sampling technique was chosen. The volunteer students were chosen at the Salahaddin University to answer the questionnaires, which allowed the researchers to obtain 413 responses among 15 different colleges $(n=413)$ in the academic year of (2020-2021). The respondents were undergraduate students from all levels of study, different gender and 15 different colleges.

\section{INSTRUMENTATION}

The study utilized the Self-Regulation Questionnaire (SRF) developed by Brown, Miller \& Lawendowski (1999), with 63 items. The scale showed a high internal and external consistency in various studies. This questionnaire included seven subscales (1- Receiving relevant information, 2- Evaluating the information and comparing it to norms, 3- Triggering change, 4- Searching for options, 5Formulating a plan, 6- Implementing the plan, and 7- Assessing the plan's effectiveness) with a 5-point Likert scale (strongly disagree, disagree, uncertain or unsure, agree, and strongly agree). The reliability of the questionnaire has been reported by the alpha coefficient of 0.82 . The scale was validated among university students, and adequate internal consistency $a=0.83$ (De la Fuente et al., 2020).

The second instrument utilized was Self-Efficacy Questionnaire (SEQ) was created by Jerusalem and Schwarzerin (Scholz et al., 2002), with a 4-point Likert scale (not at all true, hardly true, moderately true, and exactly true). This instrument contained 20 items in 1981 but was reduced to 10 items. It has been translated into 28 languages.

The third instrument utilized was Psychological Well-Being (PWB) questionnaire with 42 items version (Ryff \& Keyes, 1995). The scale was 7-point Likert (strongly agree, somewhat agree, a little agree, neither agree nor disagree, a little disagree, 
Salleh, Ismail \& Idrus | The Relationship Between Self-Regulation, Self-Efficacy, and Psychological WellBeing Among the Salahaddin University Undergraduate Students in Kurdistan.

somewhat disagree, and strongly disagree). The PWB scale measures six subscales: autonomy, environmental mastery, personal growth, positive relations with others, purpose in life, and self-acceptance. Viejo et al. (2018) have shown the validity of this instrument through Confirmatory Factor Analysis (CFA). The PWB scale has been used with college students in many countries and translated into various languages. Internal consistency coefficients for the sub-scales of the Spanish version for Morales-Rodríguez et al. (2020) research which included university students showed self-acceptance at 0.88 , positive relationships with others at 0.72 , autonomy at 0.90 , environmental mastery at 0.89 , purpose in life at 0.88 , and personal growth at 0.94 .

The reliability of all three questionnaires was measured using Cronbach's Alpha which measures internal consistency that shows how closely related a set of items are as a group. The reliability of self-regulation was 0.829 , the reliability of selfefficacy was 0.770 , and the reliability of psychological well-being was 0.759 . Hence, the validity was then assumed adequate as previous studies have applied the instruments of self-regulation, self-efficacy, and psychological well-being (Carey et al., 2004), (Scholz et al., 2002), and (Alias et al., 2020), respectively.

\section{PROCEDURE AND DATA ANALYSIS}

The formal procedures were followed during the data collection in the fieldwork. First, permission was requested from the Rectory of the Salahaddin University to administer the survey at the university. Following consent and approval, the questionnaire was distributed among undergraduate students at Salahaddin University. The researchers obtained the students' contact information from each department to answer the questionnaire and conveniently sent the Google Form link.

Once the participants answered the questionnaire, they were ensured that all responses were confidential and that they had filled the survey and answered all questions. The data was then analyzed using a statistical procedure for descriptive analysis, correlation analysis, and Multiple Regression Analysis (MRA). The collected data were computed and analyzed statistically using The Package for Social Sciences (SPSS 0.22) software. Descriptive statistics utilizes the data to provide descriptions of the population, and inferential statistics provide inferences and predictions about a population based on a sample of the population in the study. For the analysis, descriptive analysis was presented as a mean, frequency distribution, percentage, and standard deviation in this study.

Furthermore, Multiple Regression Analysis (MRA) was run to analyze the effect of self-regulation and self-efficacy on psychological well-being. A Pearson correlation was used to determine the relationship between self-regulation and self-efficacy and students' psychological well-being at the Sallahuddin University 
Salleh, Ismail \& Idrus | The Relationship Between Self-Regulation, Self-Efficacy, and Psychological WellBeing Among the Salahaddin University Undergraduate Students in Kurdistan.

\section{RESULTS}

Descriptive statistics for the prevalence level of self-regulation, self-efficacy, and psychological well-being.

The study employs a median to classify participants from high to low levels, as shown in Table 1. More than half of the participants indicated a low level of selfregulation and self-efficacy, which arrange between the mean of $m=3.2-3.5$ $\mathrm{Sd}=0.31-0.50$ respectively. However, more than half of the students showed a higher level of psychological well-being $(\mathrm{m}=4.1, \mathrm{Sd}=0.30)$. Therefore, the Salahaddin undergraduate students lack self-regulation and self-efficacy.

Table 1. Mean, SD and Median

\begin{tabular}{|c|c|c|c|c|}
\hline $\begin{array}{ll}\text { Constructs } & \text { Levels } \\
\end{array}$ & $\begin{array}{l}\text { Mean } \\
\text { SD }\end{array}$ & High & Low & Total \\
\hline Self-regulation & $\begin{array}{c}M=3.5 \\
S d=0.31\end{array}$ & $(n=198) 48.8 \%$ & $(n=209) 51.4 \%$ & $\begin{array}{c}(\mathrm{n}=407) \\
100 \%\end{array}$ \\
\hline Self-efficacy & $\begin{array}{c}3.2 \\
\mathrm{Sd}=0.50\end{array}$ & $(n=186) 45.7 \%$ & $(n=221) 54.3 \%$ & $\begin{array}{c}(n=407) \\
100 \%\end{array}$ \\
\hline Psychological well-being & $\begin{array}{c}4.1 \\
\mathrm{Sd}=0.30\end{array}$ & $(n=207) 50.9 \%$ & $(n=200) 49.1 \%$ & $\begin{array}{c}(\mathrm{n}=407) \\
100 \%\end{array}$ \\
\hline
\end{tabular}

Correlation analysis for the relationship between self-regulation and psychological well-being.

The Pearson Product Moment Correlation analysis was used. The study checks for normality assumptions of data distributions, as shown in Table 2. Furthermore, all constructs used continuous data.

Table 2 shows a positive and statistically significant link between self-regulation and psychological well-being among the Salahaddin undergraduate students $(\mathrm{r}=0.43, \mathrm{P}=.000)$. Thus, there is a medium-size effect or correlation, as suggested by Cohen (1988).

Table 2. Person Correlation

\begin{tabular}{llccccc}
\hline $\mathbf{N}$ & Constructs & $\mathbf{1}$ & $\mathbf{2}$ & Mean & SD & $\mathbf{N}$ \\
\hline 1 & Self-regulation & - & $0.43^{* *}$ & 3.46 & 0.32 & 407 \\
2 & Psychological well-being & $0.43^{* *}$ & - & 4.08 & 0.30 & 407 \\
\hline$* *$ & P<.00 & & & & &
\end{tabular}

Correlation analysis for self-efficacy and psychological well-being among the Salahaddin undergraduate students?

The Pearson Product Moment Correlation analysis was again used. The study checks for assumptions that are normality of data distributions as shown in Table 3 and the constructs used continuous data. 
Salleh, Ismail \& Idrus | The Relationship Between Self-Regulation, Self-Efficacy, and Psychological WellBeing Among the Salahaddin University Undergraduate Students in Kurdistan.

Table 3 shows a positive and statistically significant relationship between selfefficacy and psychological well-being among the Salahaddin undergraduate students $(\mathrm{r}=0.32, \mathrm{P}=.000)$. Hence, there is a medium-size effect or correlation, as suggested by Cohen (1988).

Table 3. Person Correlation

\begin{tabular}{llccccc}
\hline $\mathbf{N}$ & Constructs & $\mathbf{1}$ & $\mathbf{2}$ & Mean & SD & $\mathbf{N}$ \\
\hline 1 & Self-efficacy & - & $0.32^{* *}$ & 3.21 & 0.50 & 407 \\
2 & Psychological well-being & $0.32^{* *}$ & - & 4.08 & 0.30 & 407 \\
\hline${ }^{* *} \mathrm{P}<.00$ & & & & &
\end{tabular}

\section{Multiple Regression Analysis (MRA) indicates that self-regulation and self- efficacy affect psychological well-being}

A multiple regression analysis (MRA) was run to investigate the effect of selfregulation and self-efficacy on the psychological well-being of the Salahaddin undergraduate students. Before running the analysis, fundamental assumptions (i.e., homoscedasticity, normality of residual error, multi-collinearity, and correlations).

Firstly, data were checked for the assumption of homoscedasticity to ascertain that the variance of errors was the same across all the predictors. The assumption of homoscedasticity was checked by analyzing the scatterplot of standardized residuals (ZRESID) along the Y-axis against the predicted values (ZPRED) along the $X$-axis. A visual inspection (see Figure 1 ) suggests that the residuals are scattered quite randomly, indicating a non-violation of the homoscedasticity assumption.

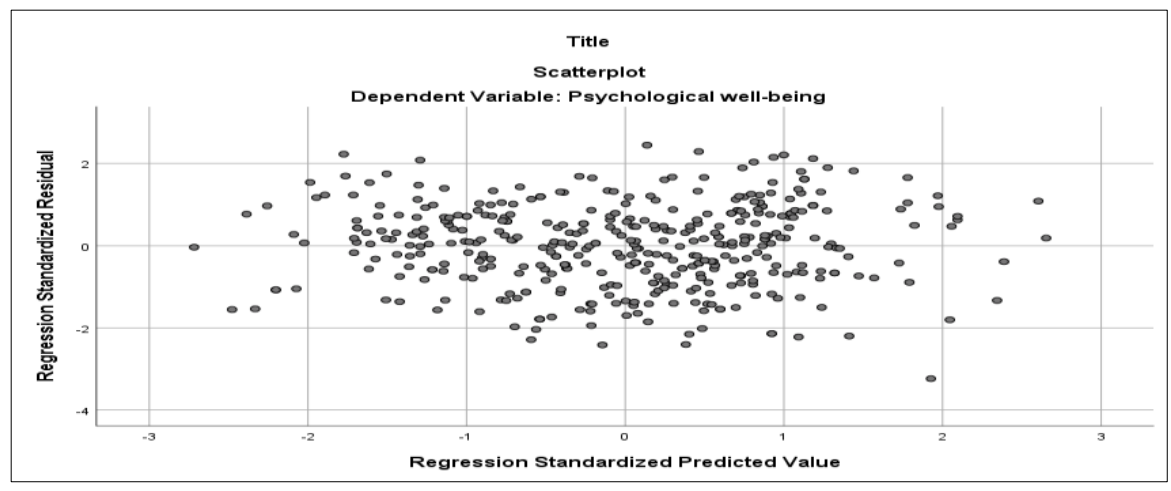

Figure 1 Regression Standardized Predicted Value

Secondly was the assumption of normality of residual error, which was examined using the normal probability plot (see Figure 2). The potted output did not indicate a serious deviation from the diagonal rule that represented normal distribution. These inspections show that this assumption of MRA was not 
Salleh, Ismail \& Idrus | The Relationship Between Self-Regulation, Self-Efficacy, and Psychological WellBeing Among the Salahaddin University Undergraduate Students in Kurdistan.

violated. Figure 2 shows the P-P plot that contains the cumulative theoretical distribution (straight line) and the cumulative distribution of the observed data.

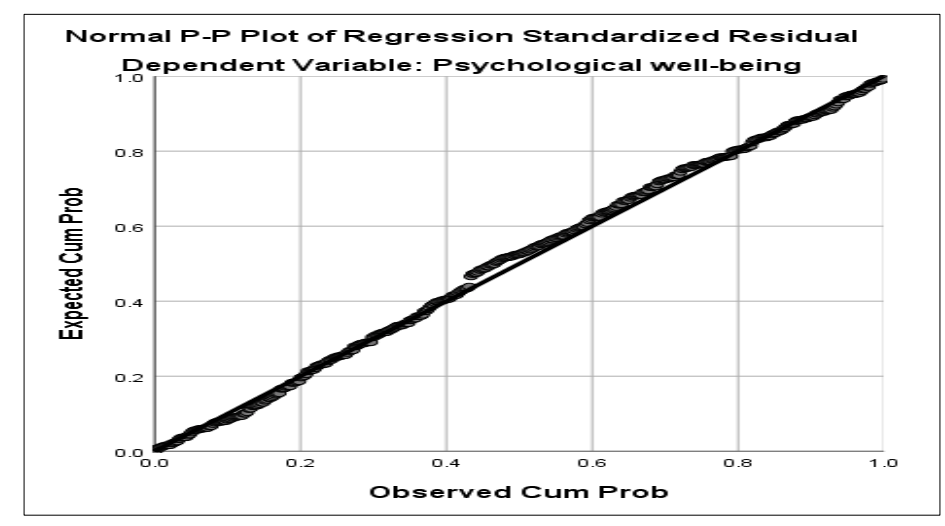

Figure 2. Observed Cum Prob

The above plot indicates the degree to which the theoretical distribution fits the observed data. The dotted line representing the cumulative distribution of the empirical data perfectly fits the straight line.

The third is the collinearity problem when the independent variables are highly correlated. Two indicators were checked to assess this assumption. They are the Variance Inflation Factor (VIF) and tolerance statistics. Table 4 shows a low tolerance value of $<0.1$, and the value of VIF for both constructs is 1.607. Hence, VIF did not exceed 3 . As such, there was no problem of multi-collinearity among the predictors.

Table 4. Value of VIF and Tolerance

\begin{tabular}{lll}
\hline Constructs & VIF & Tolerance \\
\hline self-regulation & 1.607 & 0.622 \\
self-efficacy & 1.607 & 0.622 \\
\hline
\end{tabular}

The fourth is inter-correlations. Table 5 shows the correlations between the criterion and predictor variables. The results indicate that the criterion (psychological well-being) correlates positively with two predictor variables (self-regulation and self-efficacy). Therefore, all assumptions of MRA have been achieved in this study.

Table 5. Inter-correlations between Constructs

\begin{tabular}{llccc}
\hline $\mathbf{N}$ & Constructs & $\mathbf{1}$ & $\mathbf{2}$ & $\mathbf{3}$ \\
\hline 1 & self-regulation & 1 & - & - \\
2 & self-efficacy & $0.61^{* *}$ & 1 & - \\
3 & psychological well-being & $0.43^{* *}$ & $0.32^{* *}$ & 1 \\
\hline
\end{tabular}


Salleh, Ismail \& Idrus | The Relationship Between Self-Regulation, Self-Efficacy, and Psychological WellBeing Among the Salahaddin University Undergraduate Students in Kurdistan.

Based on Table 6, this study's parameter between self-regulation self-efficacy and psychological well-being is moderate $(r=0.44)$ (Cohen, 1988). The independent variables are accounted for $19 \%$ of variances in psychological well-being with a standard error of 0.27 , while the other $81 \%$ can probably be explained by another possible variable that is not studied in this research.

Table 6. Model Summary

\begin{tabular}{ccccc}
\hline Model & $\mathrm{R}$ & R square & $\begin{array}{c}\text { Adjusted R } \\
\text { square }\end{array}$ & $\begin{array}{c}\text { St. Error of } \\
\text { the estimate }\end{array}$ \\
\hline 1 & .435 & .189 & .185 & .2714461 \\
\hline
\end{tabular}

Table 7 shows the results of ANOVA, which illustrate that the model is significant, or that, in other words, at least one of the predictors is statistically significant $(\mathrm{F}=(2,404) 47.027, \mathrm{P}=0.00)$.

Table 7. ANOVA

\begin{tabular}{llcccc}
\hline & Sum of & & & & \\
Model & Squares & df & Mean Square & F & Sig. \\
Regression & 6.930 & 2 & 3.465 & 47.027 & $.000^{\mathrm{b}}$ \\
\hline Residual & 29.768 & 404 & .074 & & \\
Total & 36.698 & 406 & & & \\
\hline
\end{tabular}

a. Dependent Variable: psychological well-being

b. Predictors (constant): self-efficacy, self-regulation

Table 8 shows that only one of the two predictors significantly affects psychological well-being: self-regulation (Beta=0.0.36, $\mathrm{t}=6.668$, and $\mathrm{P}=.000$ ). Based on the results of beta wight, one unit of students' self-regulation could increase the students' psychological well-being by 0.357 .

Table. 8 Coefficients

\begin{tabular}{|c|c|c|c|c|c|c|}
\hline \multirow{2}{*}{\multicolumn{2}{|c|}{ Model }} & \multicolumn{2}{|c|}{$\begin{array}{l}\text { Unstandardized } \\
\text { Coefficients }\end{array}$} & \multicolumn{2}{|l|}{$\begin{array}{l}\text { Standardized } \\
\text { Coefficients }\end{array}$} & \multirow[b]{2}{*}{ Sig. } \\
\hline & & B & Std. Error & Beta & $\mathrm{t}$ & \\
\hline \multirow[t]{3}{*}{1} & (Constant) & 2.686 & .147 & & 18.305 & .000 \\
\hline & Self-regulation & .357 & .054 & .379 & 6.668 & .000 \\
\hline & Self-efficacy & .049 & .034 & .083 & 1.459 & .145 \\
\hline
\end{tabular}

Dependent variable: psychological well-being

Thus, based on the results, the predicted equation can be stated as follows:

$\mathrm{Y}$ (psychological well-being) $=2.686+0.357^{*}$ (self-regulation) $+0.049^{*}($ selfefficacy) 
Salleh, Ismail \& Idrus | The Relationship Between Self-Regulation, Self-Efficacy, and Psychological WellBeing Among the Salahaddin University Undergraduate Students in Kurdistan.

\section{DISCUSSION}

The following conclusion was drawn based on the obtained data from the respondents from the questionnaire.

The result showed that more than half of the participants had a low level of selfregulation and self-efficacy $(\mathrm{m}=3.2-3.5, \mathrm{Sd}=0.31-0.50$, respectively). In other words, self-regulation and self-efficacy were low among the Salahaddin undergraduate students. This finding is in contrast to most previous studies (Durand-Bush et al., 2015; Short et al., 2016; Gagnon et al., 2016), which have revealed a high level of self-regulation among undergraduate students. Other studies have also indicated a high level of self-efficacy among their participants (Gielnik, 2020), (Eliyana et al., 2020), (Alhadabi \& Karpinski, 2020). Furthermore, (Ersöz, 2017) showed that university students had a high self-efficacy and psychological well-being.

Experts describe self-regulation and self-efficacy as the most important element in academia. Self-regulation increases academic success, social competence, and positive development (Zimmerman, 2000). Self-regulation connects individuals' performance by setting priorities, planning activities, and monitoring progress (Beeftink et al., 2012). Students with a high level of self-efficacy will be better predictors of academic outcome than previous achievements or mental ability (Los, 2014). High self-efficacy also allows the high-level ability of communication (Wildauer, 2017). However, the finding of this study is not harmonious with the results of previous studies due to the different sets of academic programs and students' backgrounds. Also, there could be some inconsistencies between students' expectations and their actual actions throughout the study. Their motivation and their degree of self-regulation and self-efficacy may be strong, but they are unaware of.

Conversely, a high level of psychological well-being was recorded among the Salahaddin undergraduate students. The result indicated that more than half of the students showed a higher level of psychological well-being $(\mathrm{m}=4.1, \mathrm{Sd}=0.30)$, which is consistent with (Viejo et al., 2018) study that found a high level of psychological well-being among participants. Another study also showed a high level of psychological well-being (Oravecz et al., 2020). However, the finding of the present study is in contrast with (Dodd et al., 2021) which found a low level of psychological well-being due to the pandemic, with about $33.8 \%$ of participants having a low level of psychological well-being and $31.5 \%$ of students had a very low level of psychological well-being. Furthermore, a low level of psychological well-being was recorded among college students who had a low level of optimism and high level of stress during Coronavirus (Genç \& Arslan, 2021).

This study presented two important findings to indicate the relationship between self-regulation and self-efficacy with psychological well-being. The result demonstrated a positive and statistically significant relationship between selfregulation and psychological well-being $(\mathrm{r}=0.43, \mathrm{P}=.000)$ and self-efficacy and 
Salleh, Ismail \& Idrus | The Relationship Between Self-Regulation, Self-Efficacy, and Psychological WellBeing Among the Salahaddin University Undergraduate Students in Kurdistan.

psychological well-being $(\mathrm{r}=0.32, \mathrm{P}=.000)$ among undergraduate students at Salahaddin University. In other words, the current research has shown that if students have strong self-regulation and self-efficacy, their psychological wellbeing will be high as well. This finding is consistent with previous studies. Students' self-regulation was significantly related to physicians and medical students (Gagnon et al., 2016). Describing, acting, awareness, and psychological well-being were most strongly related to self-regulation (Short et al., 2016). In addition, a unique relationship was revealed between self-regulation, general externalizing behavior problems, and specific problems of inattention (Lonigan et al., 2017). There was also a relationship between self-efficacy and psychological well-being among students (Siddiqui, 2015). Also, the relationship has been found among intimacy, commitment, marital satisfaction, interpersonal interaction, and self-efficacy on social network sites (Ruggieri et al., 2021). Another study showed that self-efficacy was related to students' scientific knowledge (Beck \& Blumer, 2021).

Furthermore, theoretically based on Social Cognitive Theory, the relationships between environmental factors and social experiences with the learning and well-being of students were highlighted. The social cognitive theory includes the dynamic connection between the person, behavior, and the environment. This theory demonstrates the relationship of self-efficacy and self-regulation in the students' well-being (Saroughi, 2021).

Another finding of the current study is that self-regulation can affect psychological well-being, but self-efficacy was incapable of impacting psychological well-being. In other words, self-regulation increased the Salahaddin university students' psychological well-being by 0.357 . Based on the present study's finding, self-regulation is therefore concluded to affect psychological well-being, while self-efficacy does not. The impact of selfregulation on psychological well-being has been revealed in the majority of previous researches, and self-regulation capacity can significantly impact the levels of stress, psychological well-being, and mental health functioning (Durand-Bush et al., 2015). Also, self-regulation influences purpose in life and environmental mastery as two dimensions of psychological well-being, and psychological well-being can be predicted positively through self-regulation capacity (Gagnon et al., 2016). Another result showed that planning, monitoring, controlling, and reflecting as self-regulation characteristics affected the psychological well-being of university students to increase academic achievement (Wang et al., 2021). Moreover, self-regulation significantly predicted students' psychological well-being, even at the next stages of their study (Fomina et al., 2020). Another finding showed a significant effect of selfregulation on students' learning engagement (Doo \& Bonk, 2020).

Theoretically, self-regulation allows students to consider multiple experiences across various realms: academic achievement, personality, social skills, and psychological well-being (McMillan, 2010; Pintrich, 2004). This finding is 
Salleh, Ismail \& Idrus | The Relationship Between Self-Regulation, Self-Efficacy, and Psychological WellBeing Among the Salahaddin University Undergraduate Students in Kurdistan.

consistent with previous literature and the study's findings. However, the result of the current study showed that self-efficacy could not affect psychological wellbeing, while numerous previous researches have indicated the impact of selfefficacy on psychological well-being. Many researchers have debated the opposite of the present finding. For example, Siddiqui (2015) found a significant influence of self-efficacy on psychological well-being among male and female undergraduate students. According to Bandura, self-efficacy is distinguished as peoples' beliefs about their ability to produce an appropriate level of performance for improving human production and individuals' well-being (Pajares \& Schunk, 2002). Some studies have indicated the effect of self-efficacy on psychological well-being, but this research discovered no impact, therefore concluding that students are less attentive and self-disciplined. Nevertheless, many factors may have influenced the respondents,s including a lack of motivation, university environment, teaching style, a lack of encouragement, parental style, and students' lack of knowledge of their ability or sense in diverse situations.

\section{CONCLUSION}

The current research was driven by a lack of studies on the relationship between self-regulation, self-efficacy, and psychological well-being among Kurdish undergraduate students at Salahaddin University. The result showed a low level of self-regulation and self-efficacy, while psychological well-being was high. Furthermore, self-regulation and self-efficacy were statistically significantly related to psychological well-being. Besides that, the effect of self-regulation on psychological well-being was found among undergraduates, but the study did not find the impact of self-efficacy on psychological well-being.

The findings have provided helpful guidance in applying further techniques to enhance self-regulation, influencing psychological well-being and the interaction between key constructs. Moreover, the results showed a poor degree of selfregulation and self-efficacy, contributing to identifying the causes through more concern. The results discussed and compared to previous research, and the opinions of certain experts in the area have been documented.

\section{REFERENCES}

Abdulkarim, K. A., \& Suud, F. M. (2020). Evaluation of madaris curriculum integration for primary muslim education in Mindanao: An assessment of the influence of psychology. International Journal of Islamic Educational Psychology, 1(2), 89-100. https://doi.org/10.18196/ijiep.v1i2.9736

Alhadabi, A., \& Karpinski, A. C. (2020). Grit, self-efficacy, achievement orientation goals, and academic performance in University students. International Journal of Adolescence and Youth, 25(1), 519-535. 
Salleh, Ismail \& Idrus | The Relationship Between Self-Regulation, Self-Efficacy, and Psychological WellBeing Among the Salahaddin University Undergraduate Students in Kurdistan.

\section{https:/doi.org/10.1080/02673843.2019.1679202}

Alias, N. S., Hashimah, I., Hashim, M., \& Yahaya, M. H. (2020). Psychometric properties of the 42- item version of ryff's s psychological well-being scale among working women in Malaysia. Journal of Human Development and Communication, 9, 23-28.

Bandura, A. (1994a). Self-efficacy. In V. S. Ramachaudran (Ed.), Encyclopedia of human behavior (Vol. 4, pp. 71-81). New York: Academic Press.

Bandura, A. (1994b). Self-efficacy. In V. S. Ramachaudran (Ed.), Encyclopedia of Human Behavior (Vol. 4, pp. 71-81). New York: Academic Press.

Bandura, R. E. (1996). Self-efficacy in changing societies. In Journal of Cognitive Psychotherapy (Vol. 10, Issue 4). https:/ / doi.org/10.1891/0889-8391.10.4.313

Beck, C. W., \& Blumer, L. S. (2021). The relationship between perceptions of instructional practices and student self-efficacy in guided-inquiry laboratory courses. CBE Life Sciences Education, 20(1), 1-9. https://doi.org/10.1187/cbe.20-04-0076

Behjoo, B. M. (2013). The relationship among self-efficacy, academic self-efficacy, problem-solving skills and foreign language achievement. [Thesis, Hacettepe University]. Turkey.

Beeftink, F., Van Eerde, W., Rutte, C. G., \& Bertrand, J. W. (2012). Being successful in a creative profession: The role of innovative cognitive style, selfregulation, and self-efficacy. Journal of business and psychology, 27(1), 71-81. https://doi.org/10.1007/s10869-011-9214-9

Brown, J.M., Miller, W.R., Lawendowski, L.A. (1999). The self-regulation questionnaire. In: VandeCreek, L, Jackson, TL. (Eds.). Innovations in clinical practice: A sourcebook. Vol. 17, pp. 281-292. Sarasota, FL: Professional Resource Press/Professional Resource Exchange.

Carey, K. B., Neal, D. J., \& Collins, S. E. (2004). A psychometric analysis of the self-regulation questionnaire. Addictive Behaviors, 29(2), 253-260. https://doi.org/10.1016/j.addbeh.2003.08.001

Coghlan, D., \& Brydon-Miller, M. (2014). The SAGE encyclopedia of action research. London: SAGE Publications. https:/ / dx.doi.org/10.4135/9781446294406 
Salleh, Ismail \& Idrus | The Relationship Between Self-Regulation, Self-Efficacy, and Psychological WellBeing Among the Salahaddin University Undergraduate Students in Kurdistan.

Cohen, J. (1988). Statistical power analysis for the behavioral sciences, Hillsdale. (2nd ed). Lawrence Erlbaum Associates, Publishers

Deci, E. L., \& Ryan, R. M. (2008). Self-determination theory: A macro theory of human motivation, development, and health. Canadian Psychology, 49(3), 182-185. https://doi.org/10.1037/a0012801

Dela Fuente, J., Peralta-Sánchez, F. J., Martínez-Vicente, J. M., Sander, P., GarzónUmerenkova, A., \& Zapata, L. (2020). Effects of self-regulation vs. External regulation on the factors and symptoms of academic stress in undergraduate $\begin{array}{lllll}\text { students. Frontiers in Psychology, 11, } 1773 . & \end{array}$ https:// doi.org/10.3389/fpsyg.2020.01773

Dierkes, L. (2020). Reactivity testing on self-regulation and psychological well-being in the daily life of students - an experience sampling study. The University of Twente, Department of Positive Psychology and Technology (PPT).

Diener, E. (2000). Subjective well-being: The science of happiness and a proposal for a national index. American Psychologist, 55(1), 34-43. https://doi.org/10.1037/0003-066X.55.1.34

Dodd, R. H., Dadaczynski, K., Okan, O., McCaffery, K. J., \& Pickles, K. (2021). Psychological well-being and academic experience of university students in australia during covid-19. International Journal of Environmental Research and Public Health, 18(3), 1-12. https:/ / doi.org/10.3390/ijerph18030866

Doo, M. Y \& Bonk, C. J. (2020). The effects of self-efficacy, self-regulation and social presence on learning engagement in a large university class using flipped learning. Journal of Computer Assisted Learning, 36(6) 997-1010. https://doi.org/10.1111/jcal.12455

Durand-Bush, N., Mcneill, K., Harding, M., \& Dobransky, J. (2015). Investigating stress, psychological well-being, mental health functioning, and selfregulation capacity among university undergraduate students: Is this population optimally functioning?. Canadian Journal of Counselling and Psychotherapy, 49(3), 253-274.

Eliyana, A., Musta'In, Sridadi, A. R., \& Aviantari, N. (2020). Linking self-efficacy on motivation and entrepreneurial achievements. Systematic Reviews in Pharmacy, 11(8), 328-334. https:/ / doi.org/10.31838/srp.2020.8.50 
Salleh, Ismail \& Idrus | The Relationship Between Self-Regulation, Self-Efficacy, and Psychological WellBeing Among the Salahaddin University Undergraduate Students in Kurdistan.

Ersöz, G. (2017). The role of university students' general self-efficacy, depression and psychological well-being in predicting their exercise behavior. Journal of $\begin{array}{llll}\text { Education and Training } & 110 .\end{array}$ http://dx.doi.org/10.11114/jets.v5i3.2209

Feist, J., Feist, G. J., \& Roberts, T. (2013). Theories of personality (9th Ed). New York: McGraw-Hill.

Fomina, T., Burmistrova-Savenkova, A., \& Morosanova, V. (2020). Self-regulation and psychological well-being in early adolescence: A two-wave longitudinal study. Behavioral Sciences, 10(3), 67. https:/ / doi.org/10.3390/bs10030067

Gagnon, M.-C. J., Durand-Bush, N., \& Young, B. W. (2016). Self-regulation capacity is linked to well-being and burnout in physicians and medical students: Implications for nurturing self-help skills. International Journal of Wellbeing, 6(1), 101-116. https:// doi.org/10.5502/ijw.v6i1.425

Genç, E., \& Arslan, G. (2021). Optimism and dispositional hope to promote college students' subjective well-being in the context of the COVID-19 pandemic. Journal of Positive School Psychology, 5(2), 1-10. https://doi.org/10.47602/jpsp.v5i2.255

Ghonsooly, B. \& Ghanizadeh, A., (2013). Self-efficacy and self-regulation and their relationship: A study of Iranian EFL teachers. The Language Learning Journal, 41(1), 68-84. http:// dx.doi.org/10.1080/09571736.2011.625096

Gielnik, M. M., Bledow, R., \& Stark, M. S. (2020). A dynamic account of selfefficacy in entrepreneurship. Journal of Applied Psychology, 105(5), 487-505. https://doi.org/10.1037/ap10000451

Giuntoli, L., Condini, F., Ceccarini, F., Huta, V., \& Vidotto, G. (2021). The different roles of hedonic and eudaimonic motives for activities in predicting functioning and well-being experiences. Journal of Happiness Studies, 22, 1657-1671. https:/ / doi.org/10.1007/s10902-020-00290-0

Howatt, W. A. (2011). Roles of internal locus of control and self-efficacy on managing job stressors and ryff's six scales of psychological well-being. [Doctoral thesis, Walden University]. United States.

Klassen, R. M. and Usher, E. L. (2010), Self-efficacy in educational settings: Recent research and emerging directions. Advances in Motivation and Achievement, 16 
Salleh, Ismail \& Idrus | The Relationship Between Self-Regulation, Self-Efficacy, and Psychological WellBeing Among the Salahaddin University Undergraduate Students in Kurdistan.

Part A, 1-33. https:// doi.org/10.1108/S0749-7423(2010)000016A004

Lonigan, C. J., Spiegel, J. A., Goodrich, J. M., Morris, B. M., Osborne, C. M., Lerner, M. D., \& Phillips, B. M. (2017). Does preschool self-regulation predict later behavior problems in general or specific problem behaviors?. Journal of abnormal child psychology, 45(8), 1491-1502. https:/ / doi.org/10.1007/s10802$\underline{016-0260-7}$

Los, R. E. B. (2014). The effects of self-regulation and self-efficacy on academic outcome. [Master thesis, University of South Dakota]. United States.

Mongiovi, B. (2018). The relationship between self-regulation and perceived autonomy of psychological well-being among fifth-grade christian private school students. [Doctoral thesis, Liberty University]. United States.

McMillan, J. H. (2010). The practical implications of educational aims and contexts for formative assessment. In Andrade, H. L. \& Cizek, G. J. (Ed). Handbook of formative assessment (pp. 41-58). Routledge. https://doi.org/10.4324/9780203874851

Montroy, J. J. (2014). The development of behavioral self-regulation across preschool and its association with academic achievement. [Doctoral thesis, Michigan State University]. United States.

Motlagh, S. E., Amrai, K., Yazdani, M. J., Abderahim, H. A., \& Souri, H. (2011). The relationship between self-efficacy and academic achievement in high school students. Procedia - Social and Behavioral Sciences, 15, 765-768. https://doi.org/10.1016/j.sbspro.2011.03.180

Oravecz, Z., Dirsmith, J., Heshmati, S., Vandekerckhove, J., \& Brick, T. R. (2020). Psychological well-being and personality traits are associated with experiencing love in everyday life. Personality and Individual Differences, 153. http://dx.doi.org/10.1016/i.paid.2019.109620

Pajares, F., \& Schunk, D. H. (2002). Self and self-belief in psychology and education: a historical perspective. In J. Aronson (Ed.) (2002), Improving Academic Achievement. New York: Academic Press. https://doi.org/10.1016/B978-012064455-1/50004-X.

Pintrich, P. R. (2004). A conceptual framework for assessing motivation and selfregulated learning in college students. Educational Psychology Review, 16, 385- 
Salleh, Ismail \& Idrus | The Relationship Between Self-Regulation, Self-Efficacy, and Psychological WellBeing Among the Salahaddin University Undergraduate Students in Kurdistan.

\section{7. http://dx.doi.org/10.1007/s10648-004-0006-x}

Ramli, P. A. M. (2017). Parental and peer attachments, and psychological well-being as predictors of academic engagement among college students in Malaysia. [Doctoral thesis, International Islamic University Malaysia]. Malaysia.

Roberts, K. A. (2007). Self-efficacy, self-concept, and social competence as resources supporting resilience and psychological well-being in young adults reared within the military community. [Doctoral thesis, Fielding Graduate University]. United States.

Ruggieri, S., Bonfanti, R. C., Passanisi, A., Pace, U., \& Schimmenti, A. (2021). Electronic surveillance in the couple: The role of self-efficacy and commitment. Computers in Human Behavior, 114. http://dx.doi.org/10.1016/j.chb.2020.106577

Ryff, C. D., \& Keyes, C. L. (1995). The structure of psychological well-being revisited. Journal of Personality and Social Psychology, 69(4), 719-727. https:// doi.org/10.1037//0022-3514.69.4.719

Ryff, C. D. (1989). Happiness is everything, or is it? Explorations on the meaning of psychological well-being. Journal of Personality and Social Psychology, 57(6), 1069-1081. https://doi.org/10.1037/0022-3514.57.6.1069

Ryff, C. D., \& Singer, B. (1996). Psychological well-being: meaning, measurement, and implications for psychotherapy research. Psychotherapy and psychosomatics, 65(1), 14-23. https://doi.org/10.1159/000289026

Ryff, C. D. (2013). Psychological well-being revisited: Advances in the science and practice of eudaimonia. Psychotherapy and Psychosomatics, 83(1), 10-28. https://doi.org/10.1159/000353263

Saroughi, M., \& Kitsantas, A. (2021). Examining relationships among contextual, motivational and wellbeing variables of immigrant language-minority college students. Innovative Higher Education, 46, 1-19. https://doi.org/10.1007/s10755-020-09520-y

Scholz, U., Doña, B. G., Sud, S., \& Schwarzer, R. (2002). Is general self-efficacy a universal construct? Psychometric findings from 25 countries. European Journal of Psychological Assessment, 18(3), 242-251. https://doi.org/10.1027//1015-5759.18.3.242 
Salleh, Ismail \& Idrus | The Relationship Between Self-Regulation, Self-Efficacy, and Psychological WellBeing Among the Salahaddin University Undergraduate Students in Kurdistan.

Short, M. M., Mazmanian, D., Oinonen, K., \& Mushquash, C. J. (2016). Executive function and self-regulation mediate dispositional mindfulness and wellbeing. Personality and Individual Differences, 93, 97-103. https:// doi.org/10.1016/j.paid.2015.08.007

Siddiqui, S. (2015). Impact of self-efficacy on psychological well-being among undergraduate students. The International Journal of Indian Psychology, 2(3), 516. http://dx.doi.org/10.25215/0203.040

Taştan, S. B. (2014). The relationship between psychological empowerment and psychological well-being: The role of self-efficacy perception and social

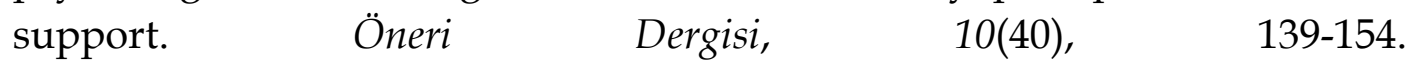
http://dx.doi.org/10.14783/od.v10i40.1012000360

Trudel-Fitzgerald, C., Millstein, R. A., von Hippel, C., Howe, C. J., Tomasso, L. P., Wagner, G. R., \& VanderWeele, T. J. (2019). Psychological well-being as part of the public health debate? Insight into dimensions, interventions, and policy. BMC public health, 19(1), 1712. https:// doi.org/10.1186/s12889-019-8029-x

Vázquez, C., Hervás, G., Rahona, J. J., \& Gómez, D. (2009). Psychological wellbeing and health. Contributions of positive psychology. Annual of Clinical and Health Psychology, 5, 15-27.

Viejo, C., Gómez-López, M., \& Ortega-Ruiz, R. (2018). Adolescents' psychological well-being: A multidimensional measure. International Journal of Environmental Research and Public Health, 15(10). https://doi.org/10.3390/ijerph15102325

Wang, H., Yang, J., \& Li, P. (2021). How and when goal-oriented self-regulation improves college students' well-being: A weekly diary study. Current Psychology: A Journal for Diverse Perspectives on Diverse Psychological Issues. Advance online publication. https://doi.org/10.1007/s12144-020-01288-W

Wildauer, J. M. (2017). Reflected Academic self-efficacy: How teacher behavior influences self-efficacy in the classroom [Master thesis, Minnesota State University] United States.

Zappala, C. R. (2007). Well-being: The correlation between self-transcendence and psychological and subjective well-being (Order No. 3297586). Available from Publicly Available Content Database. (304744014). Retrieved from 
Salleh, Ismail \& Idrus | The Relationship Between Self-Regulation, Self-Efficacy, and Psychological WellBeing Among the Salahaddin University Undergraduate Students in Kurdistan.

https://www.proquest.com/dissertations-theses/well-being-correlationbetween-self-transcendence/docview/304744014/se-2

Zhou, M., \& Brown, D. (2015). Educational learning theories (2nd Ed). In Education Open Textbooks. https://oer.galileo.usg.edu/education-textbooks/1

Zimmerman, B. J. (2000). Self-Efficacy: An essential motive to learn. Contemporary Educational Psychology, 25(1), 82-91. https:// doi.org/10.1006/ceps.1999.1016 